\title{
Spin Pass Exercise Model on Rugby Game
}

\author{
David \\ Postgraduate in State University of Jakarta, Indonesia
}

\begin{abstract}
This study aims to develop a spin pass exercise model in rugby game to obtain empirical data about the effectiveness of the spin pass training model on rugby game at DKI Jakarta Rugby Club. The method which is used in this study is Research and Development method of Borg and Gall which consists of ten steps. The subject of the research is DKI Jakarta rugby club athlete. The final result of this study is a model guidebook and a spin pass training video model on rugby games at DKI Jakarta Rugby Club with a total of 18 final models that have gone through expert evaluation, trial and revision, and effectiveness has been tested. The effectiveness of the spin-pass training model in rugby game at DKI Jakarta Rugby Club uses the "t-test" technique. Data from the results of the pretest and posttest spin-pass exercise on rugby games with a significance level of 0.05. Data on pretest male pretest and post-test results were 4.20 with a post-test of 6.27 while purti pre-test athletes are 3.72 with a posttest of 5.33 (at a significance level of 0.05), then it shows that the results of the increase in posttest class are higher compared to the male and female athletes pretest group. Thus it can be stated that, the model of spin pass training in rugby game at the DKI Jakarta Rugby Club is effectively used to improve the results of male and female athletes' spin pass. Thus it can be stated that, the spin pass training model in rugby game at the DKI Jakarta Rugby Club is effectively used to improve the results of the spin pass.
\end{abstract}

Keywords : exercise model; spin pass; rugby game

\section{Introduction}

In the sports game of rugby there are several basic techniques that must be mastered namely passing, receiving and kicking. Basically these techniques must be mastered by the players, because it is the initial capital to be able to develop games and attacks in matches. In Indonesia alone rugby players at club, university, college and regional levels still lack the mastery of these basic techniques well. Especially passing which always makes the attack channel become blocked when done not well.

The main thing in carrying out an attack on a rugby game is passing, where passing is the first step in the rugby game. If done not well, the game and the attack pattern will not run smoothly, so good passing skills are needed.

Good skills can occur if continuous training is done to get good results. Of the several types of passing that exist in rugby games, one of them is a spin pass that must be able to be properly controlled by the players. The purpose of the spin pass is to help the team in carrying out attacks, so that the game can be mastered well and can even produce a try.

During this time the players do the spin pass technique to launch attacks are always hampered so that attacks tend to be monotonous and break down like a ruck is too often done so that opponents easily read the movement of the attack. This is due to the lack of methods or spin pass training models obtained. It is necessary to do a spin pass exercise model so that players can master and do good and far-reaching passing to support various attacks.

For this reason the researchers conducted a study entitled " Spin Pass Exercise Model on Rugby Game". The researcher aims to increase the number of variations and models of spin pass exercises carried out by the players so that they do not feel bored with monotonous training models, especially the passing training model. 


\section{Review of Literature}

\subsection{Concept of Model Development}

Research is a scientific activity to obtain correct knowledge about a problem. Research can also be interpreted as knowledge obtained in the form of facts, concepts, generalizations, and theories that enable humans to understand phenomena and solve problems faced (Etta Mamang Sangadji, 2010, p. 1). Research has a variety of types. There is a division of the types of research based on research objectives, research methods used, and the field of study discussed in the study (James Tangkudung, 2016, p. 5). In the world of education research methods that are widely used include experimental methods, qualitative research, surveys and research development ( $\mathrm{R} \& \mathrm{D})$.

$\mathrm{R} \& \mathrm{D}$ is an abbreviation of research and development or commonly called research and development. Research and development is research to create new products or develop existing products based on an analysis of existing needs in the field (James Tangkudung, 2016).

Models can also be interpreted as tools or objects that mimic. In other terms the model is also interpreted as goods or real objects, for example to make a multi-storey building an architecture must make a miniature or a picture of the actual building, so that the building has a definite reference. So the exercise model can be interpreted as a way of organizing a learning atmosphere to achieve certain goals. This model is compiled and formulated for development research which later aims to produce a product in the form of a training model. In grouping research based on function and application in education and the length of results used, namely research and development. Research is divided into several forms, namely basic research, applied, evaluation, development and urgency. Development research is research not to test theory, but the results will be tested in the field and then revised so that the results will be satisfactory.

\subsection{Concept of the Model Developed}

Model is something that describes the pattern of thinking. A model usually describes the whole concept that is interrelated, as a systematic procedure in organizing learning to achieve learning goals, as well as an approach to learning or training activities. Model is a representation of both visual and verbal, the model presents something or complex or complicated information into something simpler or easier.

Models have the same meaning as approaches, strategies, or learning methods. Nowadays, there have been many kinds of training methods developed from simple to complex and complex models that require many tools in their application. While the purpose of the definition is represent of several phenomena that exist in the real world.

In this study, we will use the Borg and Gall development model where the development model guides researchers step by step in detail, and this model also allows practice groups to interact actively because they establish systematic strategies and training methods. The analysis of the tasks described in the Borg and Gall models are arranged in detail and the objectives of hierarchical special training and repeated trials can provide reliable system results.

\subsection{Exercise}

If we want to have an achievement or want a healthy body, of course it requires practice. Exercise is a systematic process of repetitive practice, with days increasing the amount of training load and intensity of the exercise (Harsono, 2107, p. 12). 
Meanwhile, according to Bompa, exercise is a systematic activity in a long time, gradually increased and individual, aimed at forming a human who functions physiology and psychology to fulfill the demands of the task (Bompa \& Claro, 2009, p. 4).

Exercises in inappropriate ways will affect development, both physiologically and psychologically. Exercise is an activity carried out systematically and planned in improving the functional body. In sports activities, exercises are useful for improving skills (Faizal Chan, 2012, p. 2)

The implementation and implementation of training programs have different interpretations, these differences occur with various alternatives including, the knowledge that the trainer has, or wants to find shortcuts in achieving optimal achievement. The principle of exercise physiology in sports to achieve optimal performance is; (1). Continuous, continuous and progressive exercise, (2). Each function is unique, exercise must be specific, and (3). The quantity of exercise includes the intensity, time and frequency of exercise (Thomas R. Baechle \& Wayne L. Westcott, 2015, p. 105).

\subsection{Spin Pass}

Spin passes use aero dynamic ball capabilities for the purpose of passing. When the operand is carried out at a great distance, the direction of the spiral ball will maintain flight direction and accuracy. When the speed and rotation of the ball helps the direction of flying, the ball will be difficult to catch. If a spiral operand is carried out at a short distance, the person who will pass the pass must pass smoothly so that the recipient of the ball will easily accept. As a consequence, spiral operands should be used as needed to save the ball quickly from a dense area to a more empty area to get a chance to fight.

According to Castellano "The distribution of players on the pitch during attacking and defending is a key-performance indicator when measuring spatial strategy" in the journal (Castellano, Silva, Usabiaga, \& Barreira, 2016).

Many factors influence the choice of attacking systems, but the main goal is always to make attacks that get maximum production from the players (Lee Rose, 2013, p. 127). Moura stated that "It is known that attacking and defending imply different collective spatial organizations" (Castellano et al., 2016). In the statement of Moura, it is known that attacking and maintaining it has a different collective role. In attacking, it requires special exercises that have been carefully coordinated while undergoing training.

\subsection{The Nature of Rugby Sports}

History records that in 1823, at a school soccer match in the town of Rugby, England, a boy named William Webb Ellis took the ball and ran towards the opposing goal line. Two centuries later, Rugby Soccer has evolved into one of the most popular sports in the world, where millions of people play, watch, and enjoy rugby games. Rugby has etiquette that has been maintained for years. Not only played by rules, but in the spirit of regulation. Through discipline, self-mastery, and respect for others, can foster a sense of friendship and fair play attitude, which confirms that rugby is a healthy game. From the school yard to the Rugby World Cup and offering a unique experience of involvement in the Rugby game (International Rugby Board, n.d.).

Rugby is a game with the ball as the main object to carry over the enemy goal line and put it on the ground to get points. Rugby is a sport with unique aspects, different from other sports. The winner of the rugby match is a team whose players are able to carry the ball and make good use of the field by avoiding opponents and winning possession. The ball can be 
kicked forward, but the teammate from the ball kicker must be behind the ball when the ball is kicked. This apparent contradiction raises the need for compact team collaboration and high discipline, not individuals. Only by working in a team can players bring the ball forward towards the opposing goal line to win the match (International Rugby Board, n.d.).

Rugby 's player concise of 2 teams which divided into 15 players. The goal of each team is to have the ball, and bring it to the opponent's territory and put it in the final zone. Some types of points that can be earned in rugby are 5 points, 2 points conversion, 3 points penalty and drop goal 3 points.

Before playing rugby, it is very important to first understand what is needed. First of all, what is needed is a pair of decent football shoes. This is important to note, especially in situations where physical contact occurs. It is strongly recommended that you wear protective gear and some players choose to wear other protectors such as head guards and protective clothing as a coating that has been approved by the IRB.

\subsection{Design Model}

For the product design, the development of the form of the spin pass exercise model in the rugby game quoted from Borg and Gall which quoted from Sugiyono has the following steps:

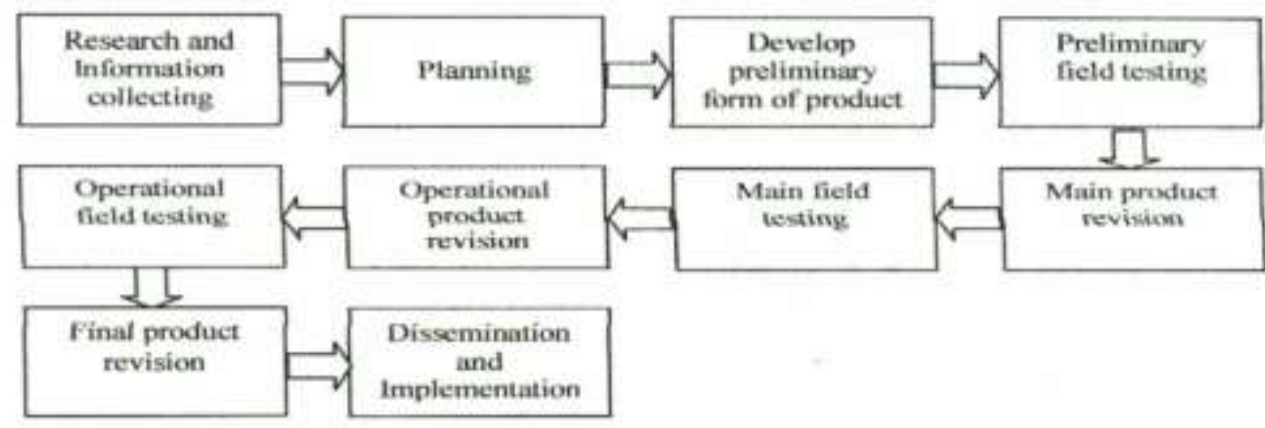

Figure 1. R \& D Development Model

Source: Borg. W. R \& Gall, M. D, Educational Research An Introduction (New York: Longman, 1983), p. 775.

\section{Research Method}

Research and Development research aims to produce new products that can be utilized in training activities to help trainers in developing training programs can also optimize the performance of athletes in achieving the expected goals of achieving the highest achievements.

The ultimate goal of this research and development $(R \& D)$ activity is to produce a spin pass training product in rugby games that can provide benefits to the trainer to make it easier for the trainer to apply training material specifically to attack. So that later can be used to improve the quality of the ability to attack.

\subsection{Characteristics of Models Developed}


The spin pass training model is a model that is designed in such a way that it can be used as a clue and clear guidance in the implementation of spin-pass exercises in rugby games, so that later in the application in practice shows maximum results.

\subsection{Expert Judgment}

The study of the results of the variation model of spin pass exercises in rugby games performed by experts, is useful for evaluating the parts of the training model that need to be repaired, eliminated or refined, this is done on the results of the design in the form of writing / drawing design and direct demonstration techniques in the field when the design of the training model is carried out by athletes. Experts involved in this $\mathrm{R}$ and $\mathrm{D}$ research are 3 experts in the field of rugby in both the academic and practice fields. The results of expert evaluations will be used as input in perfecting the design of the spin pass exercise model before being tested to small groups.

\subsection{Data Analysis}

Table 1. Research Design in Model Effectiveness Test

\begin{tabular}{llll}
\hline Subject & Pres-Test & Treatment & Post-Test \\
\hline R & $\mathrm{O}_{1}$ & P & $\mathrm{O}_{2}$ \\
\hline
\end{tabular}

The steps taken in this trial include; (1) determine the research subject group; (2) carry out the pre-test $(\mathrm{O} 1)$; (3) try the model that has been developed; (4) carry out post-test $(\mathrm{O} 2)$; (5) looking for the average score of the pre-test and post-test and compared between the two; (6) look for the difference in the second difference on average through the statistical method (t-test) to find out whether there is a significant effect of using the formula model to process the overall data of the test subjects using the t-test procedure and using the SPSS 16 application.

\section{Discussion}

In general, the results of this study include (1) Spin Pass Training Model in Rugby Games, (2) Handbook of Spin Pass Exercise Models in Rugby Games. The Spin Pass Exercise Model at the Rugby Game was held at the DKI Jakarta Rugby Club using the development method of Borg and Gall.

Based on these general objectives, researchers conduct preliminary observations or preliminary studies by conducting interviews with trainers using in-depth interviews. As well as conducting surveys or preliminary observations with athletes regarding the characteristics of the research subjects and the place to be carried out development research. This is done how needed the model will be made by the researcher.

Furthermore, the findings in the field carried out through interviews with the DKI Jakarta Rugby coaches are described and analyzed so that a formula can be obtained from the results of the data collected. The formulation of this result is descriptive and analytical, with reference to the purpose of the preliminary study.

Feasibility of the Model (Theoretical and Emperis) is the third stage of the global stage in the research, namely testing the model through expert validation and model testing. The achievement target at this stage is the achievement of a spin-pass training model in rugby games 
and the preparation of user manuals that meet the theoretical and empiric rules through systematic development. Through several activities namely expert test results, model revisions, small group trials, revisions to large group trial models, and product trials.

Expert test or expert validation is conducted to evaluate the initial product, the input given is an improvement by carrying out conceptual analysis which is then revised and validated before conducting a small group trial. This research expert judgment was carried out to get input about the initial draft draft variation of the spin pass training model on rugby games. Validation is carried out by 3 experts in the field of rugby in both the academic and practice fields.

Using a picture of a spin pass training model design on rugby games. The design of the drawing in the spin pass exercise model in the rugby game received several suggestions that were used to complete the training model before small group trials and large group trials were carried out. Suggestions from experts in outline are the model instructions, the suitability of the model to be used, the attractiveness of the model, the security of the tool to be used, the systematic development of the model, the preparation of the model to be used, and the ease of use of the model by the subject.

The evaluation and expert validation is ended with a revision of the model. In the model validation there are several revised models and there are models that are rejected, the rejected model is because athletes are not able to do the spin-pass exercise model in rugby games and the ineffective spin pass training model and there are expert suggestions and opinions to complete the spin pass training model, model revision including the size of the field used in the training process, the model instructions are clarified, the suitability of the model to be used with the conditions during the training, the attractiveness of the model, the safety of the equipment to be used, and the ease of use of the model by the subject.

In the small group trials used to try out the existing models, the models listed for testing in small groups are 18 spin pass training models in rugby games which are the revised results of expert validation. The small group test was conducted at the Rugby Club, Jakarta State University, with 25 athletes consisting of 15 male athletes and 10 female athletes.

In a large group trial carried out 18 models of spin pass exercises on rugby games which were the revised results of small group trials. The large group test was held at the Jakarta Rugby Club with 48 athletes consisting of 30 male athletes and 18 female athletes.

After conducting the results of a large group trial there was no revision in the trial of a large group of large group trials conducted to clarify from the small group trials. From the results of the large group trial there is no revision of the model that has been implemented in the spin-pass training model on rugby games, namely to be optimized to obtain good results as a reference in the product test.

To test the effectiveness of the implementation of the spin pass training model in rugby games at the DKI Jakarta Rugby Club, the "t-test" technique was used. data from the pretest and posttest results of athlete shooting using the Lilliefors test at a significance level $=0.05$. Complete calculation of $t$ test can be seen in the attachment. While the summary of the calculation results is shown in table 4.4 below. 


\section{a. Male's Spin Pass Test Results}

Table 2 Male’s Spin Pass Statistics Group

Statistics Group

\begin{tabular}{|l|l|l|l|l|l|}
\hline \multicolumn{1}{|c|}{ CLASS } & N & Mean & $\begin{array}{l}\text { Std. } \\
\text { Deviation }\end{array}$ & $\begin{array}{l}\text { Std. Error } \\
\text { Mean }\end{array}$ \\
\hline $\begin{array}{l}\text { Male's Spin Pass Test } \\
\text { Results }\end{array}$ & PRE-TEST & 30 & 4.20 & 1.15669 & .21118 \\
\cline { 2 - 5 } & $\begin{array}{l}\text { POST- } \\
\text { TEST }\end{array}$ & 30 & 6.27 & .98027 & .17897 \\
\hline
\end{tabular}

Looking at the data above the results of the Pre-test are 4.20 and the post-test results are 6.27 (in the group statistics table). From these data it can be seen that the value of the post-test class is higher or greater than the pre-test class. The difference is reinforced by a significant value smaller than 0.05 (5\%), which is 0,000 (in the Independent Sampels Test table, Sig 2 tailed column).

Tabel 3 Male's Independent Samples Test Spin Pass

\section{Independent Samples Test}

\begin{tabular}{|c|c|c|c|c|c|c|c|c|c|c|}
\hline & \multicolumn{3}{|c|}{$\begin{array}{l}\text { Levene's Test } \\
\text { for Equality of } \\
\text { Variances }\end{array}$} & \multicolumn{6}{|c|}{ t-test for Equality of Means } \\
\hline & & \multirow[t]{2}{*}{$\mathbf{F}$} & \multirow[t]{2}{*}{ Sig. } & \multirow[t]{2}{*}{$\mathbf{t}$} & \multirow[t]{2}{*}{ Df } & \multirow[t]{2}{*}{$\begin{array}{l}\text { Sig. (2- } \\
\text { tailed) }\end{array}$} & \multirow{2}{*}{$\begin{array}{l}\text { Mean } \\
\text { Differenc } \\
\text { e }\end{array}$} & \multirow{2}{*}{$\begin{array}{l}\text { Std. } \\
\text { Error } \\
\text { Differen } \\
\text { ce }\end{array}$} & \multicolumn{2}{|c|}{$\begin{array}{l}95 \% \text { Confidence } \\
\text { Interval of the } \\
\text { Difference }\end{array}$} \\
\hline & & & & & & & & & Lower & Upper \\
\hline \multirow{2}{*}{$\begin{array}{l}\text { Male's } \\
\text { Spin } \\
\text { Pass } \\
\text { Test } \\
\text { Results }\end{array}$} & $\begin{array}{l}\text { Equal } \\
\text { variances } \\
\text { assumed }\end{array}$ & $\begin{array}{l}.30 \\
5\end{array}$ & $\begin{array}{l}.58 \\
3\end{array}$ & - 7.466 & 58 & .000 & -2.06667 & .27682 & -2.62078 & $\begin{array}{l}- \\
1.5125 \\
5\end{array}$ \\
\hline & $\begin{array}{l}\text { Equal } \\
\text { variances } \\
\text { not } \\
\text { assumed }\end{array}$ & & & - & $\begin{array}{l}56.48 \\
1\end{array}$ & .000 & -2.06667 & .27682 & -2.62110 & 1.5122 \\
\hline
\end{tabular}

Based on the results of the above calculations, the Sig 2 tailed value is $0,000<0,005$, so there is a difference between the average class group post-test and the average value of 6,27 with the average group pre-test with a value of 4,20. This shows that the results of the increase in the post-test class group were higher than the pre-test group. Thus it can be stated that, the spin pass training model on rugby games for male athletes is effectively used to improve the results of the spin-off of male rugby athletes. 


\section{b. Female's Spin Pass Test Results}

Tabel 4. Female's Group Statistics Spin Pass

\section{Statistics Group}

\begin{tabular}{|l|l|l|l|l|l|}
\hline \multicolumn{2}{|c|}{ CLASS } & N & Mean & Std. Deviation & Std. Error Mean \\
\hline $\begin{array}{l}\text { Female's Spin Pass Test } \\
\text { Results }\end{array}$ & PRETEST & 18 & 3.72 & 1.27443 & .30039 \\
\cline { 2 - 6 } & POSTTEST & 18 & 5.33 & 1.18818 & .28006 \\
\hline
\end{tabular}

Looking at the data above the results of the Pre-test were 3.72 and the post-test results were 5.33 (in the group statistics table). From these data it can be seen that the value of the post-test class is higher or greater than the pre-test class. The difference is reinforced by a significant value smaller than 0.05 (5\%), which is 0,000 (in the Independent Sampels Test table, Sig 2 tailed column).

Tabel 5. Female's Independent Samples Test Spin Pass

\section{Independent Samples Test}

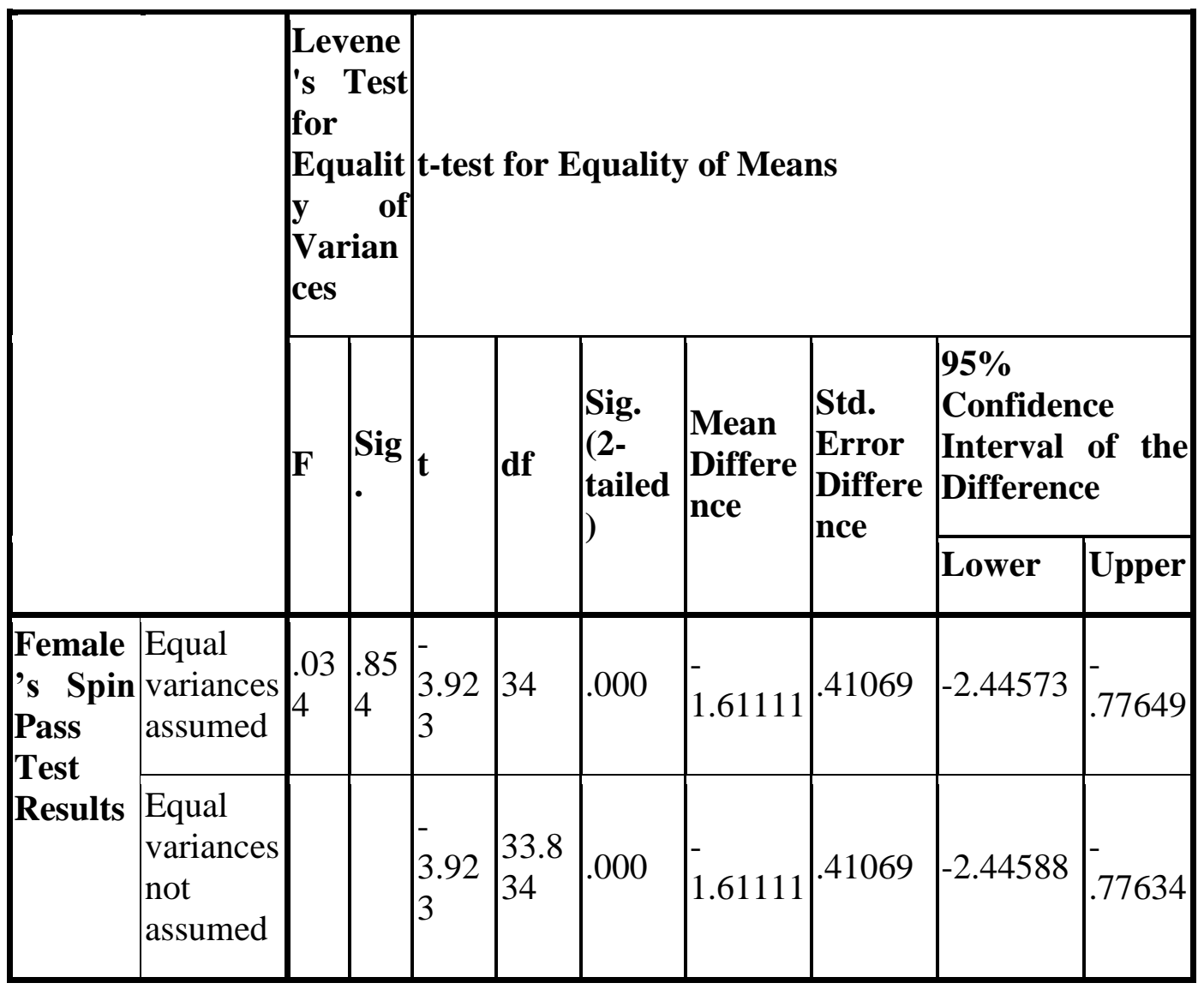

Based on the results of the above calculations, the Sig 2 tailed value is $0,000<0,005$, so there is a difference between the class group post-test and the average value of 5,33 with the 
group pre-test class average with a value of 3,72 . This shows that the results of the increase in the post-test class group were higher than the pre-test group. Thus it can be stated that, the spin pass training model in ragby games for female athletes is effectively used to improve the results of spin-off female rugby athletes.

\section{Conclusion}

From the results of field trials and discussion of the results of the study it can be concluded that: (1) Based on the results of expert evaluations and trials that have been conducted obtained the final or final model of spin pass training includes 18 models of spin pass training in rugby games at DKI Jakarta Rugby Club. (2) Based on expert validation and trials, a spin pass training model was produced in rugby games at the DKI Jakarta Rugby Club which were overall suitable for use in male and female athletes. This is based on the discussion of the results of the product trial analysis, which includes the factors of ease, attractiveness, usefulness and security and there are results from small group trials and large group trials. (3) Based on the results of the model effectiveness test, it has been empirically proven that the product results in the form of a spin pass exercise in rugby games at the DKI Jakarta Rugby Club have good effectiveness. This is based on the results of the test:

\section{a. Male's Athlete}

Which shows that the results of the average post-test with an average value of 6.27 with an average pre-test with a value of 4.20 shows that the post-test results are greater than the average pre-test results. So that it can be stated that the model of spin pass training in rugby games at the DKI Jakarta Rugby Club for male athletes is effectively used to improve the results of spin pass training with a significance value below 0.05 .

b. Female's Athlete

Which shows that the results of the post-test average are 5.33 with a pre-test average with a value of 3.72 indicating that the post-test results are greater than the average pre-test results. So that it can be stated that the model of spin pass training in rugby games at the DKI Jakarta Rugby Club for female athletes is effectively used to improve the results of spin pass training with a significance value below 0.05 .

\section{References}

Bompa, T. O., \& Claro, F. (2009). Periodization in rugby. Maidenhead: Meyer \& Meyer Sport. Castellano, J., Silva, P., Usabiaga, O., \& Barreira, D. (2016). The influence of scoring targets and outer-floaters on attacking and defending team dispersion, shape and creation of space during small-sided soccer games. Journal of Human Kinetics, 51(1), 153-163. https://doi.org/10.1515/hukin-2015-0178

Etta Mamang Sangadji. (2010). Metode Penelitian - Pendekatan Praktis dalam Penelitian. Yogyakarta: C.V Andi Offset.

Faizal Chan. (2012). Strength Training - Jurnal Media Ilmu Keolahragaan Indonesia, Cerdas Sifa, 2.

Harsono. (2107). Kepelatihan Olahraga, Teori dan Metodologi. Jakarta: Rosda. 
www.bircu-journal.com/index.php/birle emails: birle.journal@gmail.com birle.journal.qa@gmail.com

Internasional Rugby Board. (n.d.). Buku Panduan Persatuan Rugbi Untuk Pemula. Dublin 2, Ireland.

James Tangkudung. (2016). Macam-macam Metodologi Penelitian Uraian dan Contohnya. Jakarta: Penerbit Lensa Media Pustaka Indonesia.

Lee Rose. (2013). Winning basketball fundamentals (p. 127). united states.

Thomas R. Baechle \& Wayne L. Westcott. (2015). Fitness Professional's Guide to Strength Training Older Adults. Australia. 